\title{
GLOBALISASI EKONOMI DAN PENGANGGURAN: STUDI KASUS INDONESIA
}

\author{
Ari Setyawan* \\ Universitas Lampung, Indonesia \\ I Wayan Suparta \\ Universitas Lampung, Indonesia \\ Neli Aida \\ Universitas Lampung, Indonesia
}

\begin{abstract}
This study aims to examine the effect of economic globalization on the unemployment rate in Indonesia and the relationship of other macroeconomic variables such as economic growth, inflation rate, and real wage with unemployment. The data used is in the form of annual time series data from 1986 to 2018, whose research results are analyzed using the ARDL method. This study concludes that economic globalization can reduce the unemployment rate in Indonesia in the short term, although in the long term, it increases the unemployment rate. Economic growth and inflation in the short and long term have not been able to reduce the current unemployment rate, while the increase in real wages has reduced the unemployment rate in the short term, although not in the long term. By looking at these results, we need to be wary of economic globalization because economic globalization has a destructive impact in the long term. So that concrete and consistent efforts are needed from the government, the private sector, and other stakeholders so that Indonesia gets the maximum benefit from economic globalization, especially in job creation and reducing unemployment.
\end{abstract}

JEL : B22, E22

Keywords : unemployment, economic globalization, economic growth, inflation, real wages.

\begin{abstract}
ABSTRAK
Penelitian ini bertujuan melihat pengaruh tingkat globalisasi ekonomi terhadap tingkat pengangguran di Indonesia serta hubungan variabel makroekonomi lain seperti tingkat pertumbuhan ekonomi, tingkat inflasi dan tingkat upah riil dengan tingkat pengangguran. Data yang dipergunakan berupa data time series tahunan dari periode 1986 hingga 2018 yang hasil penelitiannya dianalisis menggunakan metode ARDL. Kesimpulan penelitian ini yaitu globalisasi ekonomi mampu mengurangi tingkat pengangguran di Indonesia dalam jangka pendek meskipun dalam jangka panjang malah meningkatkan tingkat pengangguran. Pertumbuhan ekonomi dan inflasi baik dalam jangka pendek dan jangka panjangnya belum mampu menurunkan tingkat pengangguran yang ada sedangkan naiknya upah riil mampu menurunkan tingkat pengangguran dalam jangka pendek meskipun tidak dalam jangka panjang. Dengan melihat hasil ini, kita perlu waspada terhadap globalisasi ekonomi karena globalisasi ekonomi ini memiliki dampak buruk dalam jangka panjang sehingga dibutuhkan upaya kongkrit dan konsisten baik dari pemerintah, swasta maupun para stakeholder lain agar Indonesia memperoleh manfaat yang sebesar-besarnya dari globalisasi ekonomi khusunya dalam upaya penciptaan lapangan kerja dan mengurangi pengangguran.
\end{abstract}

Kata Kunci : pengangguran, globalisasi ekonomi, pertumbuhan ekonomi, inflasi, upah riil.

\section{PENDAHULUAN}

Bagaimana dampak globalisasi ekonomi terhadap lapangan pekerjaan? Apakah menciptakan atau malah menghilangkannya? Studi mengenai dampak globalisasi ekonomi dan

\footnotetext{
*Email : arisetyaone1988@gmail.com

Received : 15-09-2021, Accepted : 22-12-2021, Published : 28-12-2021

P-ISSN : 2087-9954, E-ISSN : 2550-0066. DOI : http://dx.doi.org/10.26418/jebik.v10i3.49278
} 
pengangguran masih belum dapat disimpulkan dan sudah lama menyisakan perdebatan dikalangan peneliti karena hasil yang berbeda-beda. Beberapa makalah penelitian menemukan bahwa globalisasi ekonomi dan keterbukaan perdagangan dapat mengurangi tingkat pengangguran dalam jangka panjang seperti yang ditemukan oleh Felbermayr, Prat \& Schmerer (2011), Gozgor (2014), Awad \& Youssof (2016), serta Awad-Warrad (2018). Sebaliknya penelitian lain mengemukakan bahwa keterbukaan perdagangan (liberalisasi) dapat menghancurkan lapangan kerja dan meningkatkan pengangguran meskipun tidak memungkiri bahwa dalam kondisi tertentu keterbukaan perdagangan dapat menurunkan tingkat pengangguran seperti yang diungkapkan oleh Helpman \& Itskhoki (2010) dan Hasan, Mitra, Ranjan \& Ahsan (2012).

Pada era keterbukaan sekarang ini, setiap negara bersaing memperoleh benefit semaksimal mungkin dari globalisasi ekonomi tak terkecuali Indonesia. Salah satu cara yang ditempuh adalah dengan bergabung dan menjadi anggota dari beberapa kerjasama ekonomi dan perdagangan regional maupun global yang diharapkan mampu mendorong meningkatkan perekonomian negara melalui aktifitas ekspor dan impor. Saat aktifitas ekspor dan impor meningkat, dengan sendirinya akan juga meningkatkan aktifitas ekonomi yang lain. Dengan terbukanya lapangan kerja sebagai akibat dari perdagangan bebas, maka seharusnya dapat menyerap tenaga kerja dan menurunkan tingkat pengangguran.

Selain dapat dilihat dari perkembangan ekspor dan impor, globalisasi ekonomi juga dapat terlihat pada suatu indeks yang menggambarkan seberapa terbukanya perekonomian di suatu negara. Indeks ini disusun oleh Institut Ekonomi Swiss yang sering disebut indeks globalisasi ekonomi Konjunkturforschungsstelle (KOF). Indeks globalisasi ekonomi sendiri merupakan bagian dari indeks globalisasi yang terdiri dari tiga komponen yaitu ekonomi, sosial dan politik dengan 43 variabel sebagai dasar penyusunan indeks (Dreher, 2006). Besaran nilai indeks dari angka 1-100 dan angka yang mendekati nilai 100 menunjukkan semakin tinggi pula tingkat globalisasi ekonomi suatu negara yang berarti juga semakin terbukanya perekonomian suatu negara terhadap perekonomian global.

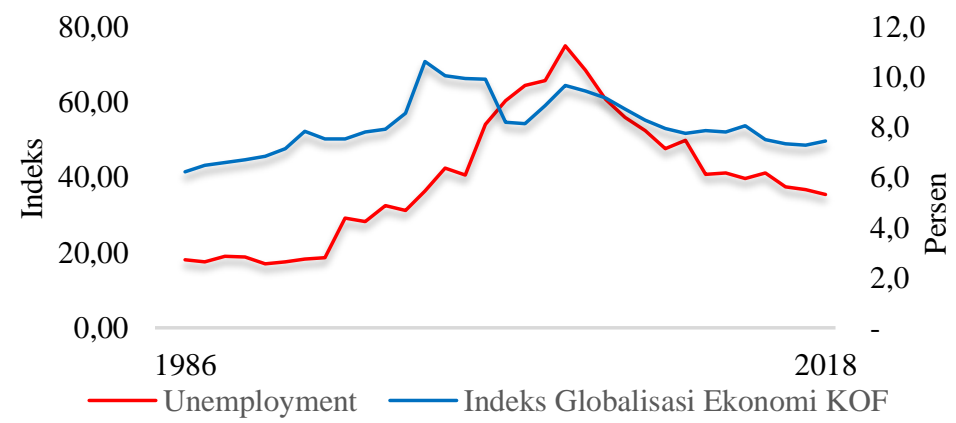

Sumber: BPS (2021) dan ETH Zurich (2021)

\section{Gambar 1. Pengangguran dan Indeks Globalisasi Ekonomi Indonesia}

Dari gambar 1 dapat dilihat bahwa secara umum indeks globaliasi ekonomi di Indonesia meningkat dari tahun ke tahun dan jika kita lihat kenaikan indeks globalisasi ekonomi juga diiringi meningkatnya pengangguran serta penurunan tingkat globalisasi ekonomi juga diiringi dengan menurunnya tingkat pengangguran di Indonesia. Fakta ini tentunya membuat kita bertanya bagaimana pengaruh globalisasi ekonomi terhadap tingkat pengangguran di Indonesia, apakah dapat mengurangi atau tidak. 
Di tengah perbedaan pendapat mengenai dampak globalisasi ekonomi serta keterbukaan perdagangan terhadap pengurangan tingkat pengangguran di suatu wilayah, globalisasi terus meluas dan tidak dapat dihindari oleh semua negara di dunia ini sebab aliran barang dan jasa, informasi, modal sampai tenaga kerja antarnegara di seluruh dunia semakin meningkat. Selain itu berbagai hambatan dalam kegiatan ekonomi dan perdagangan seperti tarif, pajak, dan peraturanperaturan pun semakin kecil yang membuat pertumbuhan ekonomi pun ikut terdampak baik langsung ataupun tidak langsung dapat meningkatkan permintaan tenaga kerja yang pada akhirnya mengurangi tingkat pengangguran. Namun kenyataannya, apakah globalisasi ekonomi bisa memberi efek seperti yang diharapkan pada kegiatan ekonomi yang pada akhirnya akan menurunkan tingkat pengangguran di Indonesia atau justru sebaliknya.

Dalam penelitian ini, peneliti akan mencoba menganalisa pengaruh globalisasi ekonomi terhadap pengangguran di Indonesia serta melihat efek variabel lain seperti tingkat pertumbuhan ekonomi, tingkat inflasi dan tingkat upah riil pada pengangguran. Rumusan dari masalah penelitian ini yaitu bagaimana globalisasi ekonomi, pertumbuhan ekonomi, inflasi dan upah riil berpengaruh pada pengangguran di Indonesia periode 1986-2018. Peneliti berharap hasil penelitian ini bisa menjadi informasi yang berguna bagi para pembuat kebijakan khususnya tentang globalisasi ekonomi dalam upaya mengatasi pengangguran di Indonesia.

\section{KAJIAN LITERATUR}

\subsection{Teori Pengangguran}

Para pakar ekonomi sepakat bahwa masalah pengangguran merupakan masalah yang sangat serius dan menjadi masalah yang paling berat dalam perekonomian karena langsung memengaruhi kehidupan manusia baik secara fisik maupun mental. Menganggur ataupun kehilangan pekerjaan bagi semua orang merupakan hal yang sangat ditakuti karena dapat menjadi sebab utama penurunan kualitas hidup karena tidak bisa memenuhi kebutuhan sehari-hari berupa sandang, pangan, papan ataupun yang lainnya serta akan menjadi beban secara psikologis. Ada beberapa teori tentang pengangguran yang sering dijadikan rujukan diantaranya teori yang dikembangkan oleh kaum klasik atau sering disebut teori Klasik dan teori yang juga sangat popular dikalangan peneliti yaitu teori dari Keynes. Kaum klasik memandang bahwa pengangguran itu bisa diatasi melalui mekanisme pasar bebas atau dengan kata lain teori klasik menitikberatkan pada sisi penawaran tenaga kerja melalui pasar secara bebas mengikuti mekanisme pasar yang ada. Penawaran tenaga kerja di pasar bebas dengan sendirinya akan menciptakan permintaan akan tenaga kerja sehingga akan tercipta suatu keseimbangan dimana semua penawaran akan diserap oleh permintaan di pasar. Menurut teori klasik, pengangguran terjadi akibat alokasi sumberdaya yang tidak tepat dan hal ini hanya bersifat sementara dan dapat diselesaikan di pasar melalui mekanisme pasar yang ada.

Berbeda dengan teori klasik, Keynes memandang bahwa permasalahan pada pengangguran akibat dari agregat demand yang rendah yang berakibat pula pada pertumbuhan ekonomi yang rendah. Penyebab pertumbuhan ekonomi yang rendah itu bukan semata-mata karena produksi yang rendah, tetapi lebih disebabkan oleh konsumsi yang rendah. Tentunya hal ini tidak bisa diserahkan melalui mekanisme pasar bebas seperti yang disarankan oleh teori klasik. Dalam mekanisme pasar bebas, saat permintaan tenaga kerja naik maka tingkat upah turun tetapi ini justru akan merugikan. Turunnya upah berarti turunnya pendapatan masyarakat dan berarti pula akan menurunkan daya beli masyarakat akan barang dan jasa. Dengan tidak terserapnya 
barang dan jasa yang ada karena penurunan daya beli akan membuat produsen dan para pengusaha merugi sehingga untuk menurunkan kerugian tersebut akan mengurangi produksi yang pada akhirnya mengurangi permintaan tenaga kerja yang berarti terjadilah pengangguran.

\subsection{Globalisasi Ekonomi, Pertumbuhan Ekonomi, Inflasi dan Upah Riil}

Globalisasi ekonomi selalu identik dengan perdagangan bebas dan perpindahan modal yang sangat cepat. Para peneliti terdahulu telah menemukan bahwa globalisasi dan keterbukaan perdagangan mendorong tingkat pertumbuhan ekonomi (Dreher, 2006; Mutascu \& Fleischer, 2011; Manwa, Wijeweera \& Kortt, 2019). Dalam model pertumbuhan Ricardian, negara yang mempunyai spesialisasi produk akan lebih diuntungkan dengan adanya perdagangan bebas karena akan memiliki keuntungan berupa produktifitas tenaga kerja apabila dibandingkan dengan negara lain yang tidak melakukan spesialisasi produk. Negara yang melakukan ekspor menggunakan sumber daya yang paling efesien dan menjadi keunggulan dari negara tersebut secara masif seperti yang diungkapkan dalam model H-O (Hecksher Ohlin), maka perekonomian negara tersebut akan semakin diuntungkan dengan adanya liberalisasi perdagangan dan keterbukaan ekonomi sehingga produksi barang dan jasa akan meningkat dan tenaga kerja banyak yang terserap. Hukum Okun telah menyatakan bahwa pengangguran dan Gross Domestic Bruto (GDP) berhubungan negatif yang berarti saat GDP naik maka pengangguran akan turun. Dengan kenaikan GDP tersebut, orang yang berkerja akan berkontribusi terhadap proses kenaikan GDP sedangkan tidak bagi orang yang menganggur.

Hubungan kenaikan harga secara terus-menerus atau inflasi telah dilukiskan pada sebuah kurva atau yang lebih dikenal dengan Kurva Philips yakni saat inflasi naik maka tingkat pengangguran akan turun karena naiknya harga barang dan jasa akan mendorong para produsen untuk lebih banyak melakukan proses produksi sehingga memerlukan lebih banyak tenaga kerja. Sedangkan hubungan antara upah dan tingkat pengangguran telah dijabarkan oleh teori klasik dan teori Keynes dimana kedua teori tersebut saling bertentangan. Teori klasik memandang upah dari sisi permintaan dan penawaran tenaga kerja dalam mekanisme pasar. Saat penawaran tenaga kerja meningkat dan tidak dapat sepenuhnya terserap dalam pasar, maka upah akan turun karena orang akan rela dibayar lebih murah daripada tidak mendapat pekerjaan dan sebaliknya jika permintaan akan tenaga kerja meningkat yang tidak diimbangi oleh jumlah permintaan tenaga kerja, maka upah akan naik karena perusahaan akan rela membayar lebih tinggi agar mendapat pekerja untuk proses produksinya. Berbeda dengan pandangan Klasik, Keynes berpendapat bahwa dalam kenyataannya, dimanapun diseluruh dunia ini, para buruh atau pekerja akan selalu memiliki perserikatan atau perkumpulan yang akan selalu menuntut kesejahteraan para anggotanya yaitu para pekerja dengan terus memperjuangkan kenaikan upah sehingga turunnya tingkat upah akan sangat kecil sekali kemungkinannya. Keynes memandang upah adalah bagian dari pendapatan masyarakat yang nantinya akan digunakan untuk konsumsi sehingga naiknya upah akan diiringi juga dengan naiknya konsumsi yang pada akhirnya dapat meningkatkan produksi dan penyerapan tenaga kerja.

\subsection{Pengaruh Liberalisasi Ekonomi Terhadap Pengangguran}

Sudah banyak makalah ataupun artikel penelitian yang membahas tentang pengaruh globalisasi ekonomi terhadap pengangguran dan menemukan beberapa perbedaan. Beberapa peneliti menemukan bahwa globalisasi ekonomi dan keterbukaan perdagangan dapat mengurangi tingkat pengangguran seperti yang dilakukan Felbermayr et al. (2011) yang menggunakan data 
panel dari 20 negara kaya OECD dari tahun 1983-2003 dan 1990-2006 dimana keterbukaan didekatkan dengan rasio ekspor dikurangi impor per GDP. Sementara itu Gozgor (2014) menggunakan data negara G7 dimana globalisasi diukur dengan indeks globalisasi ekonomi KOF, Awad \& Youssof (2016) yang meneliti di Malaysia, dan Awad-warrad (2018) yang meneliti negara-negara Arab. Sementara itu Potrafke (2013) tidak menemukan bahwa globalisasi menyebabkan deregulasi pasar tenaga kerja. Penelitian lain oleh Anyanwu (2014) menemukan perdagangan antar negara di Afrika dapat mengurangi pengangguran kaum muda. Sebaliknya beberapa peneliti lain menemukan bahwa keterbukaan perdagangan (liberalisasi) dapat menghancurkan lapangan kerja dan meningkatkan pengangguran seperti yang dilakukan Helpman \& Itskhoki (2010) dan Hasan et al. (2012) meskipun tidak memungkiri bahwa dalam kondisi tertentu keterbukaan perdagangan dapat menurunkan tingkat pengangguran.

\subsection{Pengaruh Ecomonic Growth Terhadap Pengangguran}

Sudah sangat banyak bukti empiris tentang hubungan economic growth atau pertumbuhan ekonomi dan tingkat pengangguran diantaranya ada yang menemukan bahwa Hukum Okun berlaku di 8 negara Asia (Hanusch, 2013) yang berarti pertumbuhan ekonomi dapat mengurangi pegangguran. Hasil yang serupa juga ditemukan di Arab Saudi dimana dalam kurun waktu 1990 hingga 2015, Hukum Okun juga valid di negara kerajaan tersebut Amor \& Hassine (2017). Selain itu, Gozgor (2014) juga meneliti di negara-negara G7 yang menemukan bahwa pertumbuhan GDP mempunyai pengaruh yang negatif terhadap tingkat pengangguran. Temuan ketiga peneliti tersebut dikuatkan oleh Awad \& Youssof (2016) di Malaysia. Sebaliknya, Jumhur (2020) mengemukakan bahwasannya pertumbuhan ekonomi di Indonesia belum mampu menurunkan tingkat pengangguran yang ada. Sementara itu, Tenzin (2019) yang melakukan penelitian di Bhutan tidak mendapati hubungan saling memengaruhi antara pertumbuhan ekonomi dan pengangguran dalam jangka pendek ataupun panjang.

\subsection{Pengaruh Inflasi Terhadap Pengangguran}

Bukti empiris tentang hubungan antara inflasi dan pengangguran sudah tidak terhitung lagi. Diantaranya salah satu bukti empiris tentang berlakunya Kurva Philips di negara Nigeria periode 1970-2011 atau dengan kata lain saat inflasi turun maka pengangguran akan naik demikan sebaliknya (Orji, Orji \& Okafor, 2015). Disamping itu Bhattarai (2016) menemukan bahwa ada hubungan jangka panjang antara inflasi dan pengangguran. Sementara itu, Adamu, Kaliappan, Bani \& Nor, (2018) juga menemukan bahwa inflasi menaikan tingkat pengangguran pada 35 negara di Afrika Sub-Sahara untuk periode 2007-2014. Untuk kasus perekonomian di Indonesia pun sudah banyak yang meneliti diantaranya oleh Jumhur (2020) dimana dalam penelitiannya menyatakan inflasi berhubungan positif terhadap pengangguran dalam jangka pendek.

\subsection{Pengaruh Upah Riil Terhadap Pengangguran}

Menurut Keynes, upah yang turun akan mengurangi daya beli masyarakat karena pendapat mereka berkurang dan hal ini merupakan suatu kerugian karena konsumsi akan turun sehingga barang tidak laku dan membuat produsen merugi sehingga pengusaha atau produsen akan mengurangi jumlah produksi mereka sehingga mengurangi juga tenaga kerja. Pengaruh upah riil terhadap pengangguran juga sudah diteliti oleh Awad \& Youssof (2016) di Malaysia yang menemukan bahwa upah riil berhubungan negatif terhadap tingkat pengangguran yang berarti saat upah riil meningkat maka diiringi meningkatnya permintaan akan tenaga kerja seperti yang diasumsikan oleh Keynes yaitu kenaikan upah riil adalah merupakan kenaikan pendapatan 
masyarakat yang akan mendorong meningkatnya konsumsi yang pada akhirnya akan meningkatkan produksi dan meningkatkan permintaan tenaga kerja. Dari latar belakang dan kajian literatur baik teoritis maupun empiris diatas maka didapat kerangka pemikiran penelitian sebagai berikut:

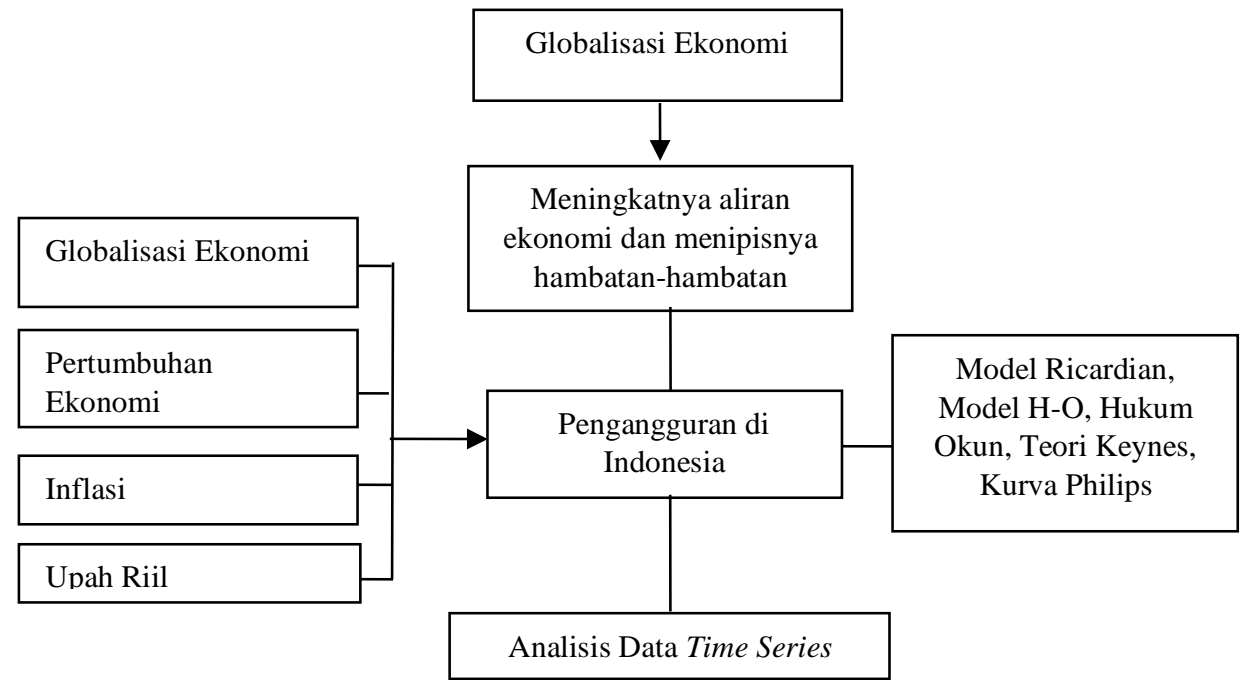

Gambar 2. Kerangka Pemikiran

Dari kerangka pemikiran tersebut, hipotesis penelitian ini adalah:

$\mathrm{H}_{1}$ : Tingkat globalisasi ekonomi diduga berpengaruh signifikan terhadap pengangguran.

$\mathrm{H}_{2}$ : Pertumbuhan ekonomi diduga berpengaruh signifikan terhadap pengangguran.

$\mathrm{H}_{3}$ : Tingkat inflasi diduga berpengaruh signifikan terhadap pengangguran.

$\mathrm{H}_{4}$ : Upah riil diduga berpengaruh signifikan terhadap pengangguran.

\section{METODE PENELITIAN}

Data dalam penelitian ini adalah data sekunder berupa data runtun waktu (time series) dari tahun 1986 sampai dengan tahun 2018. Rentang waktu penelitian yang hanya sampai tahun 2018 dikarenakan data indeks globalisasi ekonomi yang merupakan fokus utama dari penelitian ini hanya tersedia sampai pada tahun 2018 saat penelitian ini dilakukan. Tingkat pengangguran sebagai variabel terikat (dependent variable), sedangkan independent variable atau variabel bebas yaitu tingkat globalisasi ekonomi, pertumbuhan ekonomi, tingkat inflasi dan tingkat upah riil. Tingkat pengangguran yang dipergunakan yaitu tingkat pengangguran terbuka (TPT), inflasi berdasarkan perubahan dari IHK, pertumbuhan ekonomi dihitung dari perubahan PDB sedangkan upah riil didekatkan dengan upah riil dari sektor industri manufaktur dimana upah ini telah disesuaikan dengan inflasi yang terjadi pada tahun yang bersangkutan. Tingkat globalisasi ekonomi didekatkan dengan indeks globalisasi ekonomi KOF (Konjunkturforschungsstelle) yang dikeluarkan oleh Swiss Economic Institute. Indeks ini bernilai antara 0 sampai dengan 100. Semakin besar angka indeks (mendekati nilai 100) menunjukkan semakin tinggi atau besar pula aliran ekonomi aktual suatu negara dan menunjukkan semakin kecilnya hambatan-hambatan dalam perekonomian dan perdagangan suatu negara. Secara ringkas operasional variabel dan komponen penyusun indeks globalisasi ekonomi dapat dilihat pada tabel 1 . 
Tabel 1. Operasional Variabel

\begin{tabular}{|c|c|c|c|c|}
\hline Data & $\begin{array}{l}\text { Variabel } \\
(\text { Simbol })\end{array}$ & Satuan & Sumber & Keterangan \\
\hline Tingkat pengangguran & UEM & Persen & BPS & Pengangguran Terbuka \\
\hline Tingkat Globalisasi & EGI & Indeks & ETH Zurich & Indeks Globalisasi \\
\hline Ekonomi & & & & Ekonomi KOF \\
\hline Pertumbuhan Ekonomi & GROWTH & Persen & BPS & Perubahan GDP \\
\hline Tingkat Inflasi & INF & Persen & BPS & Perubahan IHK \\
\hline Upah Riil & Ln_RWG & $\begin{array}{l}\text { Ribu } \\
\text { Rupiah }\end{array}$ & BPS & $\begin{array}{l}\text { Upah Nominal Dikurangi } \\
\text { Inflasi }\end{array}$ \\
\hline
\end{tabular}

Tabel 2. Komponen Penyusun KOF Economic Globalization Indeks

\begin{tabular}{lllll}
\hline \multirow{2}{*}{ Indeks } & \multicolumn{1}{c}{$\begin{array}{c}\text { Sub- } \\
\text { Indeks }\end{array}$} & $(\boldsymbol{\%})$ & \multicolumn{1}{c}{ Komponen Penyusun } & $\begin{array}{c}\text { Bobot } \\
(\boldsymbol{\%})\end{array}$ \\
\hline \multirow{2}{*}{ Indeks } & 50 & Perdagangan barang (ekspor-impor per GDP) & 38,5 \\
& Globalisasi & & Perdagangan jasa (ekspor-impor per GDP) & 41,5 \\
& De Facto & & Keragaman mitra dagang & 16,4 \\
& atau Aliran & & Investasi asing langsung & 27,3 \\
& Aktual & & Investasi portofolio & 16,9 \\
& & Utang internasional & 25,7 \\
Indeks & & Cadangan devisa & 3,20 \\
Globalisasi & & Pembayaran pendapatan Internasional & 26,9 \\
Ekonomi & Indeks & & Peraturan perdagangan & 25,8 \\
& Globalisasi & & Pajak perdagangan & 25,3 \\
& De Jure & & Tarif & 25,4 \\
& atau & & Perjanjian perdagangan & 23,5 \\
& Hambatan- & & Pembatasan investasi & 32,2 \\
& Hambatan & & Keterbukaan neraca modal & 38,7 \\
& & Perjanjian investasi internasional & 29,1 \\
\hline
\end{tabular}

Sumber: ETH Zurich, 2021

Metode yang digunakan diadopsi dari metode yang juga dipakai Awad \& Youssof (2016) yaitu ARDL (Autoregressive Distributed Lag). Metode ini merupakan metode yang melibatkan lag atau masa nilai lampau dari variabel bebas dan lag dari variabel terikatnya dijadikan salah satu variabel penjelas tambahan dalam model regresi. Metode ini dianggap cukup sesuai dengan kenyataan bahwa dalam analisis ekonomi, respons dari perubahan suatu variabel terhadap variabel lain jarang sekali terjadi secara spontan melainkan seringkali memerlukan waktu (Gujarati, 2003). Salah satu keungulan model ini yaitu bisa melihat hubungan jangka panjang dan jangka pendek antara variabel bebas dan terikat yang diestimasi. Langkah-langkah analisis data yang dipergunakan yaitu: (1) Melakukan uji stasioneritas data, (2) Memilih lag yang paling optimum menggunakan schwarz bayesian criterion (SBC), (3) Melakukan uji kointegrasi menggunakan metode bound test cointegration untuk melihat hubungan jangka panjang, (4) Estimasi ARDL menggunakan model Error Correction Model (ECM) untuk mengetahui efek jangka pendek, (5) Melakukan pengujian kesetabilan model (goodness of fit), dan (6) Melakukan uji asumsi klasik. Adapun model yang dipakai dalam penelitian ini adalah sebagai berikut:

$$
\begin{aligned}
& U E M_{t}=a_{o}+\sum_{i=1}^{p} a_{1} U E M_{t-i}+\sum_{i=1}^{q} a_{2} E G I_{t-i}+\sum_{i=1}^{r} a_{3} G R O W T H_{t-i}+ \\
& \sum_{i=1}^{S} a_{4} I N F_{t-i}+\sum_{i=1}^{t} a_{5} L n_{-} R W G_{t-i}+\varepsilon t \ldots \ldots \ldots \ldots \ldots \ldots \ldots \ldots \ldots \ldots \ldots \ldots \ldots \ldots \ldots \ldots \ldots \\
& \text { dimana: }
\end{aligned}
$$




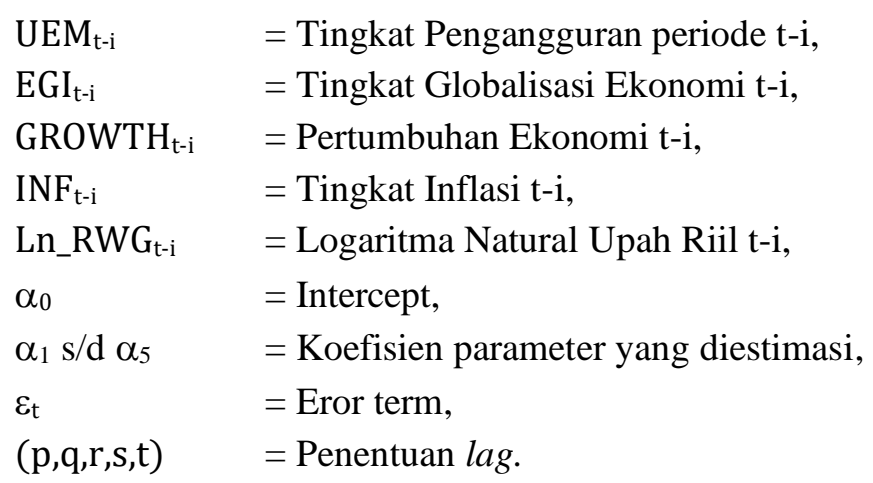

\section{HASIL DAN PEMBAHASAN}

\subsection{Deskriptif Statistik Variabel}

Statistik diskriptif pada tabel 3 dibawah menunjukkan berbagai informasi tentang keadaan data yang digunakan diantaranya nilai rata-rata (mean), nilai minimum dan maksimum, nilai tengah (median), standar deviasi, dan jumlah observasi.

Tabel 3. Statistik Diskriptrif

\begin{tabular}{lccccc}
\hline & UEM & EGI & GROWTH & INF & LN_RWG \\
\hline Mean & 5.974242 & 53.94900 & 4.949646 & 9.463333 & 6.190016 \\
Median & 5.940000 & 52.37102 & 5.500952 & 6.960000 & 6.403373 \\
Maximum & 11.24000 & 70.76031 & 7.818187 & 77.54000 & 7.870680 \\
Minimum & 2.550000 & 41.45136 & -13.12673 & 2.010000 & 4.193541 \\
Std. Dev. & 2.536776 & 7.398271 & 3.499952 & 12.65795 & 1.129327 \\
Observations & 33 & 33 & 33 & 33 & 33 \\
\hline
\end{tabular}

Dari tabel 3 terlihat bahwa nilai rerata variabel UEM sebesar 5,97 yang berarti tingkat pengangguran di Indonesia selama 33 tahun penelitian memiliki rata-rata sebesar 5,97 persen dengan nilai terendah (minimum) sebesar 2,55 persen dan nilai tertingginya sebesar 11,24 persen. Nilai rerata dari EGI sebesar 53,94, artinya tingkat globalisasi ekonomi di Indonesia selama periode penelitian memiliki rata-rata 53,94 skala indeks (1-100) dengan nilai terendah 41,45 dan nilai tertinggi 70,76. Untuk variabel GROWTH memiliki nilai mean sebesar 4,94 yang artinya selama 33 tahun periode observasi pertumbuhan ekonomi Indonesia sebesar 4,94 persen dengan pertumbuhan ekonomi terendah sebesar -13,12 persen saat terjadi krisis moneter tahun 1998 dan pertumbuhan ekonomi tertinggi sebesar 7,81 persen. Nilai rata-rata INF sebesar 9,46 artinya tingkat inflasi di Indonesai selama periode 1986-2018 rata-rata sebesar 9,46 persen. Nilai mean LN_RWG sebesar 6,19 artinya rerata upah riil sebesar 6,19 persen dengan nilai tertinggi sebesar 7,87 persen dan nilai terendah sebesar 4,19 persen. Dari uraian diatas, terlihat bahwa nilai rata-rata dari semua variabel berada pada kisaran 5,97 dan 53,94. Sebaran ini menunjukkan bahwa variasi yang cukup baik yang didukung oleh nilai standar deviasi yang relatif stabil. Kondisi ini mendukung untuk dilakukan pengujian pada tahap selanjutnya.

\subsection{Hasil Pengujian}

Dengan ADF test pada $\alpha=5$ persen, variabel EUM, EGI, dan Ln_RWG tidak stasioner pada level, tetapi variabel INF dan GROWTH stasioner. Dengan metode yang sama kembali dilakukan uji stasioner tahap first difference dan didapat hasil semua variabel sudah stasioner pada tingkat first difference. 
Tingkat Level

Tabel 4. Hasil Unit Root Test

\begin{tabular}{cccc}
\hline Variabel & t-statistik ADF & $\begin{array}{c}\text { Nilai Kritis Mac } \\
\text { Kinnon 5\% }\end{array}$ & Kesimpulan \\
\hline EUM & $-1,318518$ & $-2,957110$ & Tidak Stasioner \\
EGI & $-1,997990$ & $-2,957110$ & Tidak Stasioner \\
GROWTH & $-4,187534$ & $-2,957110$ & Stasioner \\
INF & $-5,782569$ & $-2,957110$ & Stasioner \\
Ln_RWG & 4,012815 & $-2,957110$ & Tidak Stasioner \\
\hline Tingkat 1st Difference & & & \\
\hline Variabel & t-statistik ADF & Nilai Kritis Mac & Kesimpulan \\
& & Kinnon 5 \% & \\
\hline EUM & $-4,406556$ & $-2,960411$ & Stasioner \\
EGI & $-4,729456$ & $-2,960411$ & Stasioner \\
GROWTH & $-6,737347$ & $-2,960411$ & Stasioner \\
INF & $-6,996037$ & $-2,963972$ & Stasioner \\
Ln_RWG & $-8,883218$ & $-2,963972$ & Stasioner \\
\hline
\end{tabular}

Tahap selanjutnya adalah uji lag optimum seperti terlihat pada tabel 5. Penentuan lag optimum dilakukan dengan memilih nilai kriteria yang paling kecil dari nilai AIC (Akaike Information Criterion).

Tabel 5. Hasil Uji Lag Optimal

\begin{tabular}{ccc}
\hline Variabel & Lag Optimal & Kriteria \\
\hline UEM & 3 & AIC \\
EGI & 4 & AIC \\
GROWTH & 2 & AIC \\
INF & 1 & AIC \\
Ln_RWG & 2 & AIC \\
\hline
\end{tabular}

Langkah selanjutnya yaitu uji kointegrasi Bound-Testing dengan kriteria: jika $F$-statistic dibawah nilai lower bound, maka tidak ada kointegrasi. Jika $F$-statistic berada diatas nilai upper bound maka ada kointegrasi. Jika Jika $F$-statistic berada diantara nilai upper bound maka tidak dapat disimpulkan. Berdasarkan tabel 6 didapat bahwa nilai F-statistic sebesar 11,14632 berada diatas nilai upper bound 5 persen yaitu 3,49 sehingga dapat disimpulkan terjadi kointegrasi.

Tabel 6. Hasil Bound-Testing Cointegration Test

\begin{tabular}{lcrrr}
\hline Tes Statistik & Nilai & Signifikansi & I(0) & I(1) \\
\hline F-statistik & 11,14632 & $10 \%$ & 2,2 & 3,09 \\
K & 4 & $5 \%$ & 2,56 & 3,49 \\
& & $2,5 \%$ & 2,88 & 3,87 \\
& & $1 \%$ & 3,29 & 4,37 \\
\hline
\end{tabular}

Tabel 7. Hasil Jangka Panjang

\begin{tabular}{ccccc}
\hline Variabel & Koefisien & t-Statistik & Probabilitas & Kesimpulan \\
\hline EGI & 0.287662 & 6.426697 & $0.0000^{*}$ & Signifikan \\
GROWTH & 0.789028 & 4.185635 & $0.0013^{*}$ & Signifikan \\
INF & 0.374117 & 3.613850 & $0.0036^{*}$ & Signifikan \\
LN_RWG & 1.485030 & 4.654820 & $0.0006^{*}$ & Signifikan \\
\hline
\end{tabular}

Ket : *signifikansi 5\%

Setelah melakukan penginputan dan pengujian stasioneritas, pemilihan lag optimum serta uji kointegrasi, kemudian pengolahan dilanjutkan menggunakan analisis ARDL karena 
pada hasil pengujian kointegrasi disimpulkan bahwa terdapat kointegrasi jangka panjang selanjutnya dilakukan analisis jangka pendek melalui Error Correction Model (ECM). Hasil jangka panjang yang dapat dilihat pada tabel 7 dimana semua variabel bebas mempunyai koefesien positif dan signifikan.

Tabel 8. Hasil Jangka Pendek (ARDL-ECM)

\begin{tabular}{ccccc}
\hline Variabel & Koefisien & t-Statistik & Probabilitas & Kesimpulan \\
\hline D(UEM(-1)) & 0,293433 & 2,919864 & $0,0128^{*}$ & Signifikan \\
D(UEM(-2)) & 0,528298 & 4,995738 & $0,0003^{*}$ & Signifikan \\
D(EGI) & 0,041967 & 1,754831 & 0,1048 & Tidak Signifikan \\
D(EGI(-1)) & $-0,123439$ & $-4,348942$ & $0,0009^{*}$ & Signifikan \\
D(EGI(-2)) & $-0,161013$ & $-7,107310$ & $0,0000^{*}$ & Signifikan \\
D(EGI(-3)) & $-0,089261$ & $-3,917794$ & $0,0020^{*}$ & Signifikan \\
D(GROWTH) & 0,410661 & 6,702879 & $0,0000^{*}$ & Signifikan \\
D(GROWTH(-1)) & 0,186428 & 4,611708 & $0,0006^{*}$ & Signifikan \\
D(INF) & 0,098615 & 5,558419 & $0,0001^{*}$ & Signifikan \\
D(LN_RWG) & $-1,023409$ & $-1,896230$ & $0,0823^{* *}$ & Signifikan \\
D(LN_RWG(-1)) & $-1,098015$ & $-2,402869$ & $0,0333^{*}$ & Signifikan \\
CointEq(-1)* & $-0,614298$ & $-9,733640$ & $0,0000^{*}$ & Signifikan \\
\hline R-squared & 0,882293 & & & \\
Adjusted R-squared & 0,806130 & & &
\end{tabular}

Keterangan: *signifikansi 5\%, **signifikansi 10\%

Dari hasil model jangka pendek (ARDL-ECM), didapatkan koefisien kointegrasi (CointEq(-1)) yang bernilai -0,614298 serta signifikan pada taraf 5 persen membuktikan bahwa model jangka pendek ARDL-ECM ini valid. Dari nilai Koefisien kointegrasi -0,614298 dapat diartikan bahwa variabel bebas dan terikatnya terdapat hubungan kointegrasi antara jangka panjang dan jangka pendeknya dengan kecepatan penyesuaian keseimbangan antara jangka pendek dan jangka panjangnya sebesar 0,61 tahun. Nilai Adjusted $R^{2}$ juga cukup besar yaitu 0,806130 dimana sebesar 80,61 persen variabel terikat dipengaruhi oleh variabel bebas sedangkan sisanya 19,39 persen dipengaruhi variabel lain diluar model.

Tes stabilitas model seperti cumulative sum of recursive residuals (CUSUM) dan cumulative sum of squares of recursive residuals (CUSUMSQ) diperlukan untuk menguji stabilitas parameter antara jangka pendek dan jangka panjangnya. Dari gambar 3 didapat nilai CUSUM dan CUSUMSQ (garis biru) tidak ada yang menyentuh nilai kritis 5 persen sehingga dapat disimpulkan bahwa model cukup stabil.
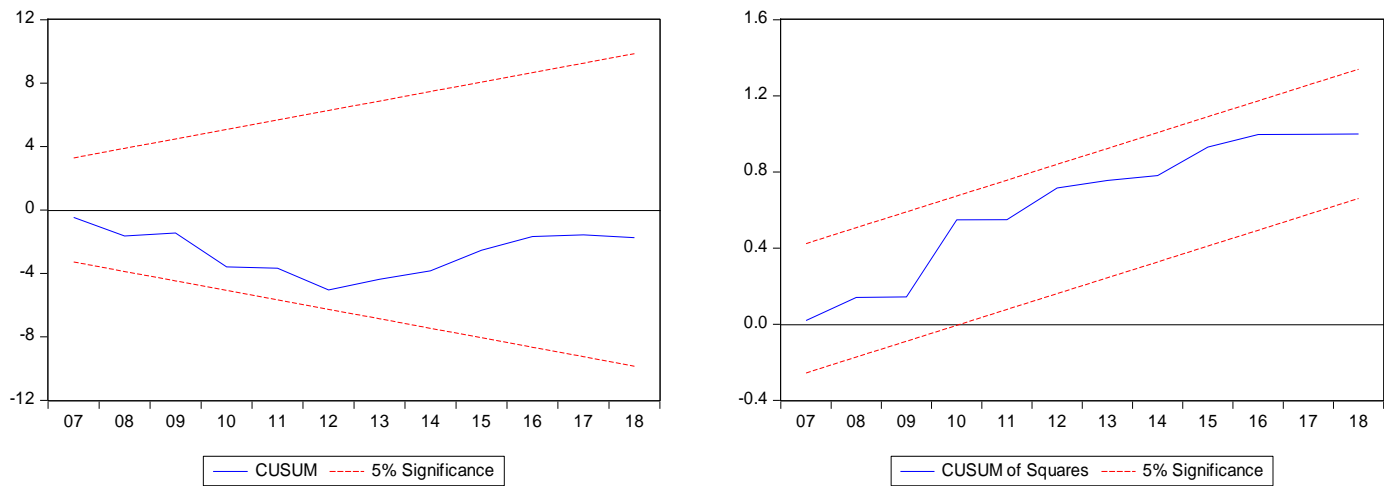

Gambar 3. Hasil Uji Stabilitas Model 
Tahap analisis selanjutnya yaitu melakukan uji asumsi klasik seperti uji normalitas, uji heterokedastisitas dan uji autokorelasi seperti pada tabel berikut. Dari tabel 9, didapat nilai probabilitas pada masing-masing uji lebih besar dari signifikansi 5 persen sehingga dapat disimpulkan model terbebas dari masalah pelanggaran asumsi klasik.

Tabel 9. Hasil Uji Asumsi Klasik

\begin{tabular}{lccc}
\hline \multicolumn{1}{c}{ Tes } & Nilai Probabilitas & Signifikasi & Kesimpulan \\
\hline Uji Normalitas & 0,325297 & $5 \%$ & Data terdistribusi normal \\
Uji Heterokedastisitas & 0,7892 & $5 \%$ & Bebas masalah heterokedastisitas \\
Uji Autokorelasi & 0.3012 & $5 \%$ & Bebas masalah autokorelasi \\
\hline
\end{tabular}

\subsection{Pengaruh Jangka Panjang Globalisasi Ekonomi Terhadap Pengangguran}

Pada tabel 6, hubungan antara globalisasi ekonomi dan pengangguran dilihat dari koefesien variabel Tingkat Globalisasi Ekonomi (EGI) bernilai positif 0,2877 hal ini berarti bahwa setiap kenaikan 1 satuan dari Indeks Globalisasi Ekonomi maka penagangguran naik sebesar 0,2877 persen cateris paribus. Hasil ini sesuai dengan temuan Helpman \& Itskhoki (2010) dan Hasan et al. (2012) namun tidak sesuai hasil penelitian dari Felbermayr et al. (2011), Anyanwu (2014) , Awad \& Youssof (2016), Gozgor (2014).

Dalam penelitian-penelitian diatas masih sulit untuk menyimpulkan bahwa globalisasi ekonomi melalui keterbukaan perdagangan memiliki dampak yang positif atau negatif terhadap pengurangan pengangguran karena variabel yang digunakan masih mengggunakan tingkat pengangguran yang umum seperti tidak diklasifikasi pengangguran menurut skill ataupun sektor. Globalisasi memiliki efek mengurangi pengangguran pada sektor yang punya tenaga kerja yang terampil dan meningkatkan pengangguran disektor yang tenaga kerjanya tidak terampil atau skill rendah (Moore \& Ranjan, 2005). Selain itu, keterbukaan perdagangan akan meningkatkan produktifitas tenaga kerja yang akan menekan pengangguran dengan menciptakan lapangan kerja baru dalam jangka panjang (Dutt, Mitra \& Ranjan, 2009).

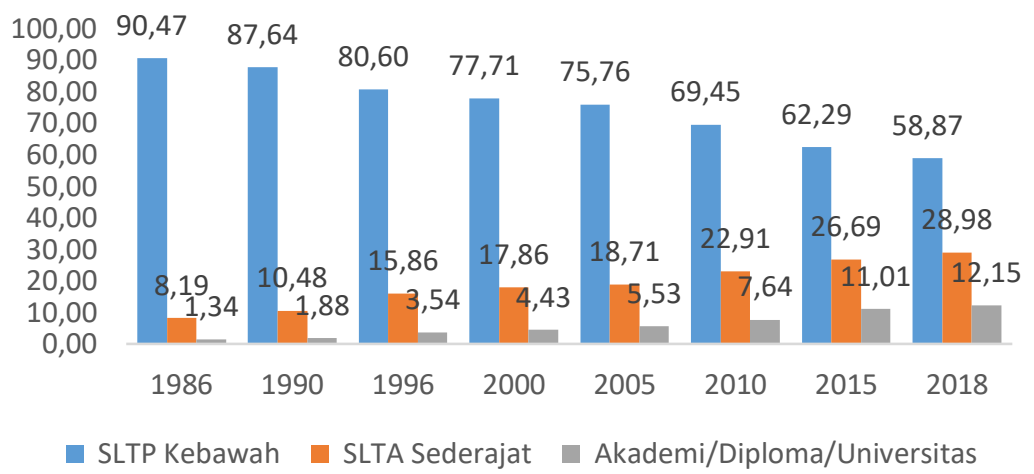

Sumber : BPS (2021)

\section{Gambar 4. Persentase Penduduk Yang Bekerja Menurut Pendidikan}

Dari data Sakernas Badan Pusat Statistik (BPS) periode tahun 1986 sampai tahun 2018 pada gambar 4 terlihat bahwa persentase pendidikan tenaga kerja Indonesia tertinggi pada tahun 2018 yaitu tamatan SLTP kebawah yang mencapai 58,87 persen, kemudian lulusan SMA/SMK sebesar 28,98 persen dan lulusan diploma serta universitas hanya 12,15 persen. Meskipun hal ini sudah cukup baik jika dibandingkan pada tahun-tahun sebelumnya, dimana tenaga kerja yang berpendidikan tamatan SLTP kebawah mencapai 90,47 persen pada tahun 1986, kemudian mulai 
menurun hingga sebesar 77,71 persen di tahun 2000 dan 69,45 persen di tahun 2010 kemudian menjadi 62,69 persen ditahun 2015. Selain dari rendahnya tingkat pendidikan, produktivitas tenaga kerja Indonesia tergolong rendah bila dibandingkan negara lain khususnya negara-negara ASEAN.

Tabel 10. Produktivitas per Pekerja di Negara ASEAN, 1990-2018

\begin{tabular}{lrrrrrr}
\hline \multirow{2}{*}{ Negara } & \multicolumn{3}{c}{ Produktifitas (Ribu US Dolar) } & \multicolumn{1}{c}{ Pertumbuhan (\%) } \\
\cline { 2 - 7 } & $\mathbf{1 9 9 0}$ & $\mathbf{2 0 0 0}$ & $\mathbf{2 0 1 0}$ & $\mathbf{2 0 1 3}$ & $\mathbf{2 0 1 8}$ & $\mathbf{1 9 9 0 - 2 0 1 8}$ \\
\hline Brunai & 203,1 & 189,8 & 167,2 & 160,4 & - & $-21,02$ \\
Singapura & 65,6 & 96,7 & 116,9 & 121,9 & 149,1 & 127,29 \\
Malaysia & 26 & 38,1 & 47,9 & 50,2 & 55,4 & 113,08 \\
Thailand & 11,3 & 17,4 & 22,4 & 24,5 & 30,8 & 172,57 \\
Indonesia & 10,9 & 13,9 & 19,2 & 21,9 & 23,9 & 119,27 \\
Filipina & 10,1 & 11,5 & 14 & 15,7 & 19,6 & 94,06 \\
Laos & 3,2 & 4,6 & 7,2 & 8,4 & 14,2 & 343,75 \\
Vietnam & 2,8 & 4,7 & 7,5 & 8,4 & 12,7 & 353,57 \\
Myanmar & 1,6 & 2,5 & 6,6 & 7,7 & 8,1 & 406,25 \\
Kamboja & - & 2,7 & 4,1 & 4,9 & 6,4 & 137,04 \\
\hline
\end{tabular}

Sumber: Asian Productivity Organization, berbagai penerbitan

Dari tabel 10, semua negara ASEAN kecuali Brunai Darussalam berhasil menaikan produktifitas tenaga kerjanya. Pada tahun 2018 Indonesia menempati urutan ke-5 di ASEAN dengan nilai produktivitas pertenaga kerja sebesar 23,9 ribu US Dollar pertahun. Peringkat pertama sampai dengan kempat ditempati oleh Brunai Darussalam, Singapura, Malaysia dan Thailand, sedangkan Indonesia berada diatas Filipina, Laos, Vietnam, Myanmar dan Kamboja. Hal ini tentu baik namun jika melihat lebih dalam lagi ternyata peningkatan itu masih jauh tertinggal bila dibandingkan dengan negara-negara tetangga kita. Bila dilihat dari data diatas, peningkatan pada produktivitas tenaga kerja Indonesia hanya 119,27 persen pada periode 1980-2018 sedangkan Laos, Vietnam, Kamboja, dan Myanmar, peningkatan produktivitas mereka hingga mencapai hingga 300an persen bahkan Myanmar mencapai 406,25 persen.

\subsection{Pengaruh Jangka Panjang Pertumbuhan Ekonomi, Inflasi dan Upah Riil terhadap Pengangguran}

Hubungan jangka panjang pertumbuhan ekonomi dan pengangguran terlihat dari nilai koefesien variabel GROWTH yaitu positif 0,7890 (tabel 6) yang berarti kenaikan 1 persen dari pertumbuhan ekonomi Indonesia justru akan membuat pengangguran meningkat juga dalam jangka panjang sebesar 0,7890 persen cateris paribus. Temuan ini sesai dengan Tenzin (2019) dan juga menguatkan hasil dari Jumhur (2020) mengemukakan bahwasannya pertumbuhan ekonomi di Indonesia belum mampu menurunkan tingkat pengangguran yang ada. Temuan ini kontradiktif bila dibanding apa yang ditemukan oleh Hanusch (2013), Gozgor (2014), Awad \& Youssof (2016) dan Amor \& Hassine (2017) yang kesemuanya menemukan bahwa pertumbuhan ekonomi dapat mengurangi pengangguran dalam jangka panjang.

Hubungan inflasi dan pengangguran dapat dilihat pada koefesien variabel Inflasi (INF) bernilai positif 0,3741 (tabel 6) yang berarti jika inflasi naik 1 persen dari inflasi maka pengangguran naik sebesar 0,3741 persen cateris paribus. Hasil ini sama dengan penelitian dari Orji et al. (2015), Bhattarai (2016), Adamu et al. (2018) serta Jumhur (2020) namun tidak sesuai temuan Gozgor (2014) dan Awad \& Youssof (2016) dimana mereka menemukan dalam jangka tejadi hubungan negatif antara inflasi dan pengangguran. 
Sementara itu, upah riil dan pengangguran memiliki koefesien positif 1,4850 (tabel 6) yang mengindikasikan bahwa dalam setiap kenaikan 1 persen dari upah riil akan meningkatkan tingkat pengangguran di Indonesia sebesar 1,4850 persen dalam jangka panjang cateris paribus. Tidak seperti yang ditemukan di Malaysia yang diteliti Awad \& Youssof (2016), yang menemukan bahwa upah riil berhubungan negatif terhadap tingkat pengangguran yang berarti saat upah riil meningkat maka diiringi meningkatnya permintaan akan tenaga kerja seperti yang diasumsikan oleh Keynes. Hal ini terjadi karena sektor manufaktur di Malaysia menjadi sektor kunci dalam pertumbuhan ekonomi mereka karena memiliki nilai tambah yang besar sehingga mampu meningkatkan pendapatan masyarakat yang berujung meningkatnya permintaan akan tenaga kerja dan menurunnya pengangguran karena konsumsi yang meningkat.

\subsection{Pengaruh Jangka Pendek Globalisasi Ekonomi Terhadap Pengangguran}

Hubungan jangka pendek tingkat pengangguran (UEM) dengan tingkat globalisasi ekonomi yang didekatkan melalui Indeks Globalisasi Ekonomi (EGI) dapat dijelaskan melalui lag (tabel 7). Pada jangka pendek, globalisasi ekonomi saat ini berpengaruh secara positif tetapi tidak signifikan $(\alpha=5 \%)$ terhadap pengangguran dengan koefesiensi sebesar 0,041967 . Namun pada lag 1, 2 dan 3 berubah menjadi negatif dan signifikan $(\alpha=5 \%)$ dengan nilai koefesien masing-masing lag sebesar $-0,123439$ pada lag 1, $-0,161013$ pada lag 2, dan -0,089261 pada lag 3 . Hasil pada lag 1, 2 dan 3 ini sejalan oleh temuan Awad \& Youssof (2016) dan Gozgor (2014) yang menemukan bahwa dalam jangka pendek globalisasi ekonomi cenderung dapat mengurangi pengangguran. Indeks globalisasi ekonomi menjelaskan aliran aktual dan hambatan-hambatan pada porsi tertentu.

Berdasarkan pendapat para ahli yang mengungkapkan bahwa pengurangan hambatan dapat mengakibatkan peningkatan pengangguran sebagai hasil dari liberalisasi perdagangan, hal ini karena pada dasarnya tenaga kerja yang bekerja pada sektor impor akan kehilangan pekerjaan mereka, sedangkan penyerapan tenaga kerja pada sektor ekspor akan membutuhkan penyesuaian dalam periode jangka panjang. Hal ini dikarenakan dalam mencapai pekerjaan pada sektor ekspor, tenaga kerja membutuhkan waktu untuk meningkatkan kapasitas skill-nya. Dalam kasus perekonomian Indonesia, dalam jangka pendek pendapat diatas tidak bisa diterima sepenuhnya karena perbedaan struktur ekonomi antara negara maju yang sektor perekonomiannnya dominan sektor sekunder dan tersier atau industri dan perdagangan sedangkan Indonesia sebagai negara berkembang masih mengandalkan sektor primer yaitu sektor pertanian sebagai penopang perekonomian. Sehingga jika pekerjaan hilang sektor ekspor dan impor akibat dari liberalisasi perdagangan maka sektor pertanian akan menjadi shock absorber dalam jangka pendek.

\subsection{Pengaruh Jangka Pendek Pengangguran, Pertumbuhan Ekonomi, Inflasi dan Upah Riil terhadap Pengangguran}

Hubungan tingkat pengangguran (UEM) dengan tingkat pengangguran itu sendiri dapat dijelaskan melalui lag (tabel 7). Pada jangka pendek, tingkat pengangguran dipengaruhi secara signifikan dan positif ( $\alpha=5 \%$ ) pada lag 1 dan 2 dengan koefesiensi sebesar 0,293433 dan 0,528298. Nilai ini menunjukkan bahwa pengangguran saat ini sangat dipengaruhi oleh tingkat pengangguran itu sendiri hingga 2 tahun sebelumnya. Setiap kenaikan 1 persen pada tingkat pengangguran pada lag 1 dan 2 maka akan meningkatkan pengangguran periode yang diestimasi (saat ini) sebesar masing-masing 0,293433 persen untuk lag 1 dan 0,528298 persen untuk lag 2 cateris paribus.

Hubungan jangka pendek tingkat pengangguran (UEM) dengan Pertumbuhan ekonomi (GROWTH) dapat dijelaskan melalui lag (tabel 7). Pertumbuhan ekonomi saat ini berpengaruh 
secara signifikan dan positif $(\alpha=5 \%)$ dalam jangka pendek terhadap pengangguran dengan koefesiensi sebesar 0,410661 dan pada lag 1 dengan koefesien sebesar 0,186428. Hal ini sejalan pada hasil jangka panjangnya dimana pertumbuhan ekonomi belum mampu menurunkan tingkat pengangguran yang ada. Hal ini sejalan dengan Jumhur (2020) yang menemukan bahwa pertumbuhan ekonomi yang ada di Indonesia belum mampu menurunkan tingkat pengangguran yang ada dalam jangka pendek. Namun hasil ini kembali bertentangan dengan apa yang ditemukan oleh Awad-warrad (2018), Awad \& Youssof (2016), Gozgor (2014), dan Hanusch (2013) yang kesemuanya menyimpulkan bahwa pertumbuhan ekonomi berhubungan negatif dengan pengangguran yang berarti dapat menurunkan pengangguran dalam jangka pendek.

Dari tabel 7 juga dapat dilihat bahwa koefesien jangka pendek variabel inflasi (INF) bernilai positif 0,098615 yang berarti kenaikan 1 persen dari inflasi membuat tingkat pengangguran naik sebesar 0,098615 persen dalam jangka pendek cateris paribus. Hal ini sejalan dengan dari Jumhur (2020) dimana dalam penelitiannya inflasi pada lag 0 hingga lag 2 berhubungan positif terhadap pengangguran di Indonesia meskipun pada lag 4 baru berhubungan negatif dan signifikan. Hasil ini ini juga sesuai dengan temuan Adamu et al. (2018) dan Orji et al. (2015). Hasil jangka pendek ini semakin menguatkan hasil jangka panjangnya dimana peningkatan inflasi di Indonesia juga diikuti oleh peningkatan jumlah pengangguran.

Hubungan jangka pendek antara tingkat pengangguran dengan upah riil dapat dijelaskan melalui lag (tabel 7). Pada jangka pendek, upah riil saat ini berpengaruh secara signifikan dan negatif ( $\alpha=10 \%$ ) dengan koefesien sebesar -1,023409 dan berpengaruh negatif dan signifikan $(\alpha=5 \%$ ) pada lag 1 dengan koefesien -1,098015. Jika upah riil periode saat diestimasi meningkat 1 persen maka tingkat pengangguran akan menurun sebesar -1,023409 dan jika upah riil naik 1 persen pada periode 1 tahun sebelumnya maka pengangguran akan turun sebesar -1,098015 cateris paribus. Hal ini sejalan dengan Awad \& Youssof (2016) namun bertentangan dengan Adamu et al. (2018). Hasil ini sesuai dengan pandangan Keynes yang memandang naiknya upah akan menaikkan konsumsi karena pendapatan masyarakat meningkat sehingga akan direspon dengan naiknya permintaan tenaga kerja untuk menambah proses produksi sehingga naiknya upah berujung pada menurunnya pengangguran.

\section{SIMPULAN DAN REKOMENDASI}

Hasil penelitian ini menunjukkan bahwa globalisasi ekonomi mampu mengurangi tingkat pengangguran di Indonesia dalam jangka pendek meskipun dalam jangka panjang malah meningkatkan tingkat pengangguran. Pertumbuhan ekonomi dan inflasi baik dalam jangka pendek dan jangka panjangnya belum mampu menurunkan tingkat pengangguran yang ada sedangkan naiknya upah riil mampu menurunkan tingkat pengangguran dalam jangka pendek meskipun menaikan tingkat pengangguran dalam jangka panjang. Dengan melihat hasil dari penelitian ini, kita perlu hati-hati terhadap globalisasi ekonomi karena globalisasi ekonomi ini memiliki dampak buruk dalam jangka panjang terhadap upaya pengurangan tingkat pengangguran meskipun dalam jangka pendek dapat mengurangi tingkat pengangguran sehingga dibutuhkan upaya kongkrit dan konsisten baik dari pemerintah, swasta maupun para stakeholder lain agar Indonesia memperoleh manfaat yang sebesar-besarnya dari globalisasi ekonomi. Pemerintah sebagai pembuat kebijakan diharapkan memberikan perhatian disemua aspek, utamanya dalam meningkatkan daya saing tenaga kerja baik dari pelatihan maupun sertifikasi kompetensi serta lebih intensif dalam link and match antara pencari kerja dengan dunia usaha. Selain itu, pemerintah, swasta dan para stakeholder 
lain juga harus mendorong minat para generasi muda untuk berwirausaha serta mendorong peningkatan daya saing umkm.

Penelitian ini memiliki keterbatasan utama yaitu hanya menggunakan empat variabel bebas untuk menjelaskan pengangguran di Indonesia. Oleh sebab itu, perlu mempertimbangkan penambahan variabel lain untuk penelitian kedepan khususnya terkait dengan keterbukaan ekonomi yang diperkirakan mempengaruhi pengangguran seperti ekspor-impor, FDI, suku bunga dan sebagainya untuk memperoleh hasil lebih baik. Keterbatasan lain yaitu penelitian ini hanya menggunakan data hingga tahun 2018 dikarenakan indeks globalisasi ekonomi yang menjadi fokus penelitian hanya tersedia sampai tahun 2018 .

\section{DAFTAR PUSTAKA}

Adamu, P., Kaliappan, S. R., Bani, Y., \& Nor, N. M. (2018). Impact of globalization on unemployment in Sub-Saharan African (SSA) countries. International Journal of Economics and Management, 12(Special Issue 2), 443-454.

Amor, M. ., \& Hassine, M. . (2017). The relationship between unemployment and economic growth: is Okun's Law valid for the Saudi Arabia case? International Journal Economics and Business Research, 14(1), 44-60.

Anyanwu, J. C. (2014). Does Intra-African trade reduce youth unemployment in Africa? African Development Review, 26(2), 286-309.

Awad-warrad, T. (2018). Trade Openness , Economic Growth and Unemployment Reduction in Arab Region. International Journal of Economics and Financial Issues, 8(1), 179-183.

Awad, A., \& Youssof, I. (2016). The impact of economic globalisation on unemployment: The Malaysian experience. Journal of International Trade and Economic Development, 25(7), 938-958.

Bhattarai, K. (2016). Unemployment-inflation trade-offs in OECD countries. Economic Modelling, 58, 93-103.

Dreher, A. (2006). Does globalization affect growth? Evidence from a new index of globalization. Applied Economics, 38(10), 1091-1110.

Dutt, P., Mitra, D., \& Ranjan, P. (2009). International trade and unemployment: Theory and crossnational evidence. Journal of International Economics, 78(1), 32-44.

Felbermayr, G., Prat, J., \& Schmerer, H. J. (2011). Trade and unemployment: What do the data say? European Economic Review, 55(6), 741-758.

Gozgor, G. (2014). The impact of trade openness on the unemployment rate in G7 countries. Journal of International Trade and Economic Development, 23(7), 1018-1037.

Gujarati, Damodar. (2003). Ekonometrika Dasar. Terjemah Sumarno Zein. Jakarta: Erlangga.

Hanusch, M. (2013). Jobless Growth? Okun'S Law in East Asia. Journal of International Commerce, Economics and Policy, 04(03), 1350014.

Hasan, R., Mitra, D., Ranjan, P., \& Ahsan, R. N. (2012). Trade liberalization and unemployment: Theory and evidence from India. Journal of Development Economics, 97(2), 269-280.

Helpman, E., \& Itskhoki, O. (2010). Labour Market Rigidities, Trade and Unemployment. Review of Economic Studies, 77(3), 1100-1137. 
Jumhur. (2020). Penerapan Autoregressive Distributed Lag Dalam Memodelkan Pengaruh Inflasi, Pertumbuhan Ekonomi, dan FDI Terhadap Pengangguran Di Indonesia. Jurnal Ekonomi Bisnis Dan Kewirausahaan (JEBIK), 9(3), 250-265.

Manwa, F., Wijeweera, A., \& Kortt, M. A. (2019). Trade and growth in SACU countries: A panel data analysis. Economic Analysis and Policy, 63, 107-118.

Moore, M. P., \& Ranjan, P. (2005). Globalisation vs Skill-Biased Technological Change: Implications for Unemployment and Wage Inequality. Economic Journal, 115(503), 391422.

Mutascu, M., \& Fleischer, A. M. (2011). Economic growth and globalization in Romania. World Applied Sciences Journal, 12(10), 1691-1697.

Orji, A., Orji, O. . I. A., \& Okafor, J. C. (2015). Inflation And Unemployment Nexus In Nigeria: Another Test of the Phillips Curve. Asian Economic and Financial Review, 5(5), 766-778.

Potrafke, N. (2013). Globalization and labor market institutions: International empirical evidence. Journal of Comparative Economics, 41(3), 829-842.

Tenzin, U. (2019). The Nexus Among Economic Growth, Inflation and Unemployment in Bhutan. South Asia Economic Journal, 20(1), 94-105. 